\title{
Using Open-Ended Story Technique in Improving Saudi University Students' Short Story Writing Skills
}

\author{
Hashem A. Al samadani (Corresponding author) \\ Department of Education, Umm Al-Qura University (Al-Qunfudah branch), Makkah, Saudi Arabia \\ E-mail: hmazawid@gmail.com \\ Salem S. Ibnian \\ Department of Education, Umm Al-Qura University (Al-Qunfudah branch), Makkah, Saudi Arabia
}

Received: 17-02- 2015

Accepted: 28-04- 2015

Published: 01-09- 2015 doi:10.7575/aiac.ijalel.v.4n.5p.227

Advance Access Published: May 2015

URL: http://dx.doi.org/10.7575/aiac.ijalel.v.4n.5p.227

\begin{abstract}
This study aimed at examining the impact of using the open-ended story technique on improving Saudi university students' short story writing skills in English as a Foreign Language (EFL). The study addressed the following questions: (1) What are the short story writing skills that university students need in EFL? and (2) What is the impact of using the open-ended story technique on improving Saudi university students' short story writing skills in EFL? The researchers developed a pre-post short story writing test to measure performance of the study's sample, which consisted of 56 English major students, and reveal effectiveness of the open-ended story technique in improving the learners short story writing skills. Findings of the study showed a positive impact for the open-ended story technique on performance of the experiment group on the post short story writing test.
\end{abstract}

Keywords: open-ended story technique, EFL, short story writing, Saudi students

\section{Introduction}

Writing is considered to be a major productive language skill that learners need to master during their schooling so as to achieve communicative competence. Researchers in foreign language teaching field conducted many studies to explore approaches, strategies and techniques that could help learners master language skills, including writing.

Elliott (1990) stressed that literature encourages students and is "motivationally effective if students can genuinely engage with its thoughts and emotions and appreciate its aesthetic qualities". Researchers who support the use of short stories in language teaching point out to several benefits of short stories. These include motivational, literary, cultural and higher-order thinking benefits. Murdoch (2002) indicated that "short stories can, if selected and exploited appropriately, provide quality text content which will greatly enhance EFL courses for learners at intermediate level of proficiency". He added that "based on short stories, instructors can create a variety of writing activities to help students develop their writing skills. Besides, short story writing forces students to discipline their writing, emphasize conciseness, and sharpen grammar skills. Self-expression is also an important ingredient in all good essays".

\subsection{Statement of the problem and questions}

Studies conducted in the field of EFL teaching indicated that EFL learners suffer from serious problems while practicing writing in the target language (Javid and Umer 2014, Alsamdani 2010, Al-Jarf 2008 and Rababah, 2003). As for the problems of ESL learners' in writing, Alsamadani (2010) stated that "writing is a complex, challenging, and difficult process because it includes multiple skills such as identification of thesis statement, writing supporting details, reviewing and editing. This complex process makes it rather difficult to teach it. The difficulty of teaching/learning of this skill is due to the fact that it involves a comprehensive knowledge of grammar, suitable vocabulary, writing mechanics (e.g., punctuation \& capitalization), organizational skills, style, and imagination".

Thus, the current study addresses the problem of poor performance of Saudi university students in writing in general and in short story writing in EFL in particular. Consequently, the study attempts to answer the following two questions:

1. What are the short story writing skills that Saudi university students need in EFL?

2. What is the impact of using the open-ended story technique on developing university students' short story writing skills in EFL?

\subsection{Objectives of the study}

The study aims at:

1. determining the short story writing skills that Saudi university students need in EFL classes

2. developing Saudi university students' short story writing skills in EFL 
1.3 Significance of the study

Outcomes of the study could help in the following fields:

1. $\boldsymbol{E F L}$ Instructors: guiding them to follow suitable techniques to upgrade their students' short story writing skills in EFL.

2. Learners: developing their short story writing skills in EFL.

3. Researchers: guiding other researchers to carry out more studies on developing students' writing skills.

\subsection{Delimitations}

1. The study is limited to developing Saudi university students' short story writing skills in EFL.

2. The study is confined to English major students at Umm Al-Qura University / Al-Qunfudah branch.

3. The study was carried out in the second term of the academic year 2013-2014, over eight weeks.

\subsection{Sample}

The sample of the study comprised 56 English major students chosen randomly from Umm Al Qura University / AlQunfudah branch.

\section{Review of Related Literature}

Creative writing is a chance to free individuals' imagination in which people get satisfaction. Through creative writing, students can use their linguistic capabilities and go deeper and further that they cannot do in oral expression. They express more personal thoughts and mental images. Therefore, creative writing tasks are motivating both for L1 and L2 students (Harmer, 2004).

Durham (1970) noted that "descriptions of objects, novels, stories, poems, plays, imaginative diaries, letters, dialogues, free writing from photographs, writing of pastiche, reviews of books, films, current events, controversial issues, writing scripts for stage or radio drama are the studies that can be used for creative writing".

As for short story writing, Pathan and Al Dersi (2013) indicated that "the role of literature, in general and short-stories in particular, in ELT classroom has always been advocated because of various advantages this use can offer for EFL teachers and learners. Literature, in the form of short-stories, makes learning English an enjoyable and attractive process for EFL learners".

Saricoban, Kucukoglu (2011) noted that "short stories can be a good source in ELT classes in almost all levels from young learners to adult learners so that they can make good use of short stories in learning the target language. While choosing the right short story, students' proficiency level, age, and interests should be taken into consideration. Another important thing is the course objectives and appropriateness of the story as content".

In addition, Collie and Slater (1987) pointed out that "stories also help to stimulate students' curiosity about the target culture and language. Integrating short-stories in EFL classrooms also paces the way to the EFL learners' involvement with rich, authentic uses of the foreign language".

On the other hand, Pardede (2011) noted that "the majority of English teachers training students basically found short stories interesting to use both as materials for self-enjoyment and of as components language skill classes".

Collie and Slater (1991) listed four advantages of using short stories for language teachers, adding that "short stories are practical as their length is long enough to cover entirely in one or two class sessions. Second, short stories are not complicated for students to work with on their own. Third, short stories have a variety of choice for different interests and tastes. Finally, short stories can be used with all levels (beginner to advance), all ages (young learners to adults) and all classes (morning, afternoon, or evening classes)."

Hismanoglu (2005) indicated that "short story can be a powerful and motivating source for writing in ESL/EFL, both as a model and as subject matter. Short story as a model occurs when students' writing becomes closely similar to the original work or clearly imitates its content, theme, organization, and /or style."

Erkaya (2005) noted that "short stories usually have a beginning, middle and an end, thus, they encourage students at all levels of language proficiency to continue reading them until the end to find out how the conflict is resolved".

As for short story elements, Ibnian (2010) indicated that "there are certain elements that should exist in the short story:

Setting: the time and place in which the story happens. Authors often use descriptions of landscape, scenery, buildings, seasons or weather to provide a strong sense of setting.

Characters: persons, or sometimes even animals, who take part in the action of a short story or other literary work.

The Conflict (problem): the struggle between two people or things in a short story. The main character is usually on one side of the central conflict. The main character may struggle against another important character, against the forces of nature, against society, or even against something inside himself or herself such as feelings, emotions or illness.

The Plot (events): the systematic chain of events which make up the short story. Each link in the chain helps to build suspense and to solve a problem.

The Solution: the outcome of the attempts to resolve the problem or conflict. 
The Theme: the theme is the controlling idea or belief of the story. It gives a basic meaning to a literary work. Generally, a theme is inferred from the other elements in the short story and often evolves through the conflict experienced by the main character".

\subsection{Review of Related Studies}

Reynolds (1983) carried out a study to identify the effects that two methodologies (Expressive Writing Methodology and Traditional Writing Methodology) have on the ability of high school students to write stories and essays. The sample of the study comprised forty-eight students, who were classified into two different groups: one group was instructed by the Expressive Writing Methodology and the other group was instructed by the Traditional Writing Methodology.

Results of the study showed no significant differences in story and essay posttest scores between the two groups were observed. No significant interaction effect on story instruction was observed, and no significant interaction effect on essay posttest scores between English achievement level and method of instruction was observed. However, a significant interaction effect on story posttest scores between English achievement level and method of instruction was observed.

Albertson and Billingsley (2001) investigated the impact of an instructional package comprising strategy instruction and self-regulation techniques on story writing. The sample of the study consisted of two gifted, middle school students. The researchers observed a number of points including story's length, fluency, story's elements, and time. Results showed positive impact of the instructional package on both participants.

Al-Jarf (2007) examined the effect of online courses on non-native freshman students to write poems and short stories in English as a foreign language. The sample of the study comprised 38 students, who were enrolled in writing, grammar, vocabulary and reading courses. They were also registered in an asynchronous online course that was used as a supplement to in-class instruction. A sample of 54 poems, short stories, plays and essays were collected from the 38 students. Each was examined in terms of theme, spelling and grammatical mistakes, style and language sophistication level. Results showed that online courses had a positive effect on the level of writing of non-native freshman students in poems and short stories genres.

Cuesta and Rincon (2010) inspected the effects of using the genre-process approach and e-portfolio dossier to improve short story writing among senior year students from a state school in Bogotá. The results of data analysis from this study revealed significant improvements in students' written production. The findings also validate the use of eportfolio dossiers as an effective learning and assessment tool.

Arif (2010) examined the use of short story to improve teaching skills of creative writing. The participants, seventh graders, were taught to write creatively using short stories as prompts for their writing. The data of the study was collected through classroom teaching sessions, observations, field notes, document analysis and semi-structured focused group interviews. Results revealed that stories have very powerful effect on students and can be used for numerous teaching strategies.

Moreover it was found that the process approach was more fruitful than the product approach.

Alnufaie, M., and Grenfell, M. (2012) conducted a study to investigate the writing strategies of 121 second-year undergraduate Saudi student who were studying English as a foreign language and for specific purposes in Jubail Industrial College (JIC). The writing strategies under investigation were the process-oriented writing strategies and product-oriented writing strategies. Findings showed that $95.9 \%$ of the participants were mixing the two kinds of strategies.

\subsection{Commentary}

Having outlined a number of studies related to the purpose of the current study, the researchers observed that some previous studies focused on some techniques and strategies to improve the learners' short story writing skills, such as the genre-process approach, e-portfolio dossier (Cuesta and Rincon ,2010), on- line courses (Al Jarf 2007) and selfregulation techniques (Albertson and Billingsley 2001).

It was clearly observed that some studies classified short story writing as an integral part of creative writing (Temizkan 2011) and (Arif 2010).

On the other hand, the related studies enriched the current study in the following aspects:

1. Highlighting short story's elements

2. Shedding light on some strategies and techniques that could help improve the learners' creative writing skills, including short story writing

3. Helping the researchers identify short story writing skills that university students need in their wiring class

\section{Methodology}

The study followed the quasi- experimental design. Two groups were chosen from Umm Al-Qura University students / Al-Qunfudah branch. One of the groups served as an experimental group (28 students) and the other as control (28 students). 


\subsection{Variables}

The independent variable:

The open-ended story technique

The dependent variable:

Performance of the experimental group in short story writing.

\subsection{Instrument}

A pre- post short story writing test was designed by the researchers so as to measure the effectiveness of the proposed technique (open-ended story) in improving students' short story writing skills. (See appendix 1)

\subsection{Procedures}

3.3.1 To answer the first question: "What are the short story writing skills needed for university students in EFL?" the researchers:

a. Reviewed the related literature in the field of short story writing.

b. Determined the short story writing skills that university students need in EFL.

3.3.2 To answer the second question: "What is the impact of using the open-ended story technique on developing Saudi university students' short story writing skills in EFL?" the researchers:

a. Prepared the pre- post test.

b. Chose the sample of the study.

c. Administered the short story writing pre- test to both groups.

d. Applied the open-ended story technique on the experimental group during writing classes.

e. Administered the short story writing post- test to both groups.

f. Collected and analyzed data.

g. Discussed the results of the study.

h. Introduced recommendations of the study.

\section{Findings and Discussion}

Having designed the tool of the study and checked its validity and reliability, It was administered to both groups before and after the implementation of the open-ended story technique.

The researchers used the Statistical Package for the Social Sciences (SPSS) to analyze data, excluding 6 incomplete papers.

First research question: What are the short story writing skills that Saudi university students need in EFL?

To identify the short story writing skills in EFL, the researchers outlined related literature in writing in TEFL field. The researchers surveyed many studies conducted in creative writing field in different environments, including the Arab world and came up with a list of skills that university students need in this field, the list included the following aspects:

1. Content and organization: this skill covered the following sub skills: availability and clarity of story elements, writing a well- constructed plot, creating coherent content and coming up with logically-sequenced events.

2. Mechanics of writing: this skill included punctuation, spelling and grammar.

3. Language use: this skill covered choosing appropriate words and using proper expressions.

4. Showing creative abilities.

Second research question: What is the impact of using the open-ended story technique on developing university students' short story writing skills in EFL?

Having used the Statistical Package for the Social Sciences (SPSS) to analyze data, the researchers came up with the following findings:

Table 1 shows that the control group's mean pre-test score was 28.67 and the post-test score was 29.00 . On the other hand, the experimental group's mean pre-test score was 27.46 and post-test score was 30.57 .

Table 1. Means and Standard Deviations of Pre and Post-test

\begin{tabular}{llll}
\hline Group & Mean & Std. Dev. & $\mathrm{N}$ \\
\hline \multirow{2}{*}{ Experimental } & & Pre: 6.95 & 28 \\
& Pre: 27.46 & Post: 8.46 & \\
\hline \multirow{2}{*}{ Control } & Post: 30.57 & Pre: 6.52 & 28 \\
& Pre: 28.67 & Post: 6.76 & \\
\hline
\end{tabular}


These statistics show that there was a difference between the mean scores of both groups.

To determine the significance of this difference and to answer the main research question (Can using open-ended story technique improve the students' short story writing skills? ), a one-way between-groups analysis of covariance was conducted to measure the effect of the open-ended story technique on students' short story writing skills.

Table 2. Tests of Between-Subjects Effects

\begin{tabular}{llllll}
\hline Source & $\begin{array}{l}\text { Type III } \\
\text { Sum of Squares }\end{array}$ & df & Mean Square & F & Sig. \\
\hline Corrected Model & $2542.908^{\mathrm{a}}$ & 2 & 1271.454 & 102.331 & .000 \\
\hline Intercept & 5.981 & 1 & 5.981 & .481 & .491 \\
\hline pre & 2508.336 & 1 & 2508.336 & 201.879 & .000 \\
\hline Group & 108.715 & 1 & 108.715 & 8.750 & .005 \\
\hline Error & 658.521 & 53 & 12.425 & & \\
\hline Total & 52884.000 & 56 & & & \\
\hline Corrected Total & 3201.429 & 55 & & & \\
\hline
\end{tabular}

a. R Squared $=.794$ (Adjusted R Squared $=.787)$

The results of the ANCOVA (as shown in table 2) show that there was a significant difference between the mean scores of the two groups on post-short story scores, $\mathrm{F}(1,53)=8.75, \mathrm{p}=.005$, partial eta squared $=.79$. The partial eta squared value indicates that $79 \%$ of the variance in students' short story scores is explained by the use of the open-ended story technique (independent variable).

\subsection{Discussion}

Based on findings of the study, it was clearly observed that the open-ended story technique had positively affected performance of the experiment group in short story writing field. The findings showed that there was a significant difference between the mean scores of the two groups on post-short story scores in favor of the experimental group.

The open-ended story technique, which was implemented over two months, provided the learners with greater opportunities to imagine new ideas and come up with different conclusions to complete the raised stories.

Studies conducted in creativity field highlighted the need to create a free atmosphere to improve individuals' creative thinking and help them come up with unique and new ideas. Thus, short story writing, which is an integral part of creative writing genres, needs a motivating and encouraging classroom atmosphere so as to help learners express their ideas freely and generate suitable ideas to complete the raised stories, a fact that was taken into account while conducting the current study.

Arif (2010) stressed that students feel ownership of their work if they are allowed to think outside the box and develop their ideas, a fact which could explain reasons behind progress in performance of the current study's experimental group, since learners were provided with great opportunities to imagine and come up with conclusions for the raised open-ended stories.

Moreover, outcomes of the current study agree with findings of Albertson and Billingsley (2001), which stressed "the positive effect of self-regulation technique on improving learners' story writing skills".

In addition, the findings were in line with Al-Jarf (2007)'s findings, which indicated "the positive impact of online courses on non-native freshman students to write poems and short stories in English as a foreign language". Furthermore, the current study outcomes were in harmony with findings of Ibnian (2010), which emphasized "the positive effect of the story- mapping technique on developing high school learners' short story writing skills in EFL in Jordan". The researchers observed the open-ended story technique contributed to sharpening students' thinking, especially that learners were provided with some story's elements, including setting (time and place) the main characters, and the problem, and they were asked to imagine new events and come up with a solution to the problem leading to a specific theme.

On the other hand, the open-ended story contributed to helping the learners identify short story elements, a fact that improved their performance on the short story post test.

\subsection{Recommendations}

Based on findings of the study, the researchers recommend:

1. Attaching more emphasis on teaching short story writing

2. Providing the students with greater opportunities in the class to express themselves freely and come up with unique ideas

3. Designing further activities that focus on improving learners' creative abilities

\section{Conclusion}

In light of findings of the study, it was clearly observed that the open-ended story technique had positively affected the learners' short story writing skills, and that was notable in performance of the experimental group on the short story post writing test. 
The suggested technique helped the learners come up with new ideas to complete the open-ended stories; since the atmosphere that was created in the class motivated them to imagine new events and conclude the stories with unique ideas. The open-ended story technique also enabled the learners to identify short story's elements, a fact that was observed in their performance on the post- short story test.

\section{References}

Albertson, L. \& Billingsley, F. (2001). Using Strategy Instruction and Self-Regulation To Improve Gifted Students' Creative Writing. Journal of Secondary Gifted Education, 12(2).

Al-Jarf, R. (2007). Online Instruction and Creative Writing by Saudi EFL Freshman Students, King Saud University, Saudi Arabia, (Online) Available: www.asian-efl journal.com

Al-Jarf , R. (2008). The Impact of English as an International Language (EIL) upon Arabic in Saudi Arabia. Asian EFL Journal, 10(4), 193-210.

Alnufaie, M., \& Grenfell. M. (2012) EFL Students' Writing Strategies in Saudi Arabian ESP Writing Classes: Perspectives on Learning Strategies in Self-Access Language Learning, Studies in Self-Access Learning Journal, 3 (4), pp. 407-422.

Alsamdani, H.A. (2010). The Relationship between Saudi EFL Students' Writing Competence, L1 Writing Proficiency, and Self-regulation. European Journal of Social Sciences, 16(1), 53-63.

Arif, T., (2010). Improving my teaching of creative writing skills by using short stories with students of secondary class in a private school. M.A thesis. Aga Khan University, Institute for Educational Development, Karach

Collie, J. \& S. Slater. (1987). Literature in the Language Classroom: A Resource Book of Ideas and Activities. Cambridge: Cambridge University press.

Cuesta, L., \& Rincón, S.,(2010). Short story student-writers: active roles in writing through the use of e-portfolio dossier. Colombian Applied Linguistics Journal 12(1), 99-115

Durham, M. K. (1970). Creative writing. English Studies in Africa, 13(1), 155-174

Elliott, R. (1990). Encouraging reader-response to literature in ESL situations. ELT Journal 44(3), 191-198.

Erkaya, O. (2005). Benefits of Using Short Stories in the EFL Context. Asian EFL Journal, 8.

Harmer, J. (2004). How to teach writing. Pearson Education Limited, Malaysia.

Hismanoglu, M., (2005). Teaching English Through Literature. Journal of Language and Linguistic Studies Vol.1, No.1, April 2005

Ibnian, S. (2010). The Effect of Using Story -Mapping Technique on Developing Tenth Grade Students' Short Story Writing Skills in ESL. Canadian Centre of Science and Education, 3(4), 183-19

Javid, C., \& Umer, M. (2014). Saudi EFL learners' writing problems: a move towards solution. Proceeding of the Global Summit on Education GSE 2014 (E- ISBN 978-967-11768-5-6) 4-5 March 2014, Kuala Lumpur, Malaysia.

Murdoch, G. (2002). Exploiting well-known short stories for language skills development. IATEFL LCS SIG Newsletter 23, 9-17.

Pardede, P. (2011). Short Stories Use in Language Skills Classes: Students' Interest and Perception. Conference: 4th Annual International Seminar Faculty of Language and Literature Satya Wacana Christian University, At Salatiga Pathan, M., \& Al-Dersi, Z. (2013). Investigating the Role of Short-Stories in Overcoming the Problems Faced by the Libyan EFL Learners in Reading Comprehension Skill. The Criterion An International Journal in English, 12 1-8 Rababah, G. (2003). Communication Problems facing Arab learners of English: A personal perspective. TEFL Web Journal, 2(1), 15-30.

Reynolds, A. (1983). The Effects of Teaching Expressive Writing (Integrated within the writing process) on the Improvement of Student Writing Skills at the High School Level. Dissertation Abstracts International, 44 (4), 10-11.

Saricoban, A., \& Kucukoglu, H. (2011) Using literature in EFL class: short story. 1st International Conference on Foreign Language Teaching and Applied Linguistics. May 5-7 2011 Sarajevo. 
Appendix

\section{Short Story Writing Test}

1. Write suitable title and end to the following open- ended story.

John and his younger brother Peter were alone in their apartment. Their parents had gone to visit their friends in the nearby city. Suddenly the doorbell rang. Peter ran to the door thinking that his parents had come home; he unlocked the door and opened it. Outside, there was

2. Ahmad, fifteen years old, is an orphan boy, his father died two years ago and his family suffers from poverty. Ahmad is one of the best students in his class, he hopes to continue his education and study engineering .... write a short story (between 12- 15 lines). 